\title{
Four Decades of Neurodegenerative Disease Research: How Far We Have Come!
}

\author{
Anne B. Young \\ Neurology Service, Massachusetts General Hospital, Boston, Massachusetts 02114
}

\section{Introduction}

My patients frequently ask, "Why does research take so long?", "Why is progress so slow?", and "Why don't we have effective therapies for these devastating diseases?" At first thought, these questions seem correct. But with further contemplation, it is also remarkable how far we have come-even in my professional lifetime.

\section{Clinical neurology}

Neurology, in 1969, was focused on diagnosis of the disease, primarily by physical examination. People going into neurology were always warned that it was a specialty in which one could diagnose, but not treat. Epilepsy, migraine, and Parkinson's disease (PD) had the most effective therapies.

At this time, diagnosis depended almost completely on the physical exam because examination of the brain during life was very primitive. Plain $\mathrm{x}$-rays could show a skull fracture or a shift in the pineal gland (as a measure of a mass). Pneumoencephalograms were $\mathrm{x}$-rays of air that was injected into the spinal fluid space. The air would flow into the ventricles when the person was turned upside down and back and the air distribution could show masses or anomalies that impinged on the ventricular system. Myelograms depended on injecting dye into the spinal fluid space and looking for blockage or distortion of the spaces. Arteriograms revealed blood vessels after injecting dye, which delineated aneurysms, arteriovenous malformations, arteritis, and masses. Electroencephalograms showed evidence of seizure or slowing neuron function from a mass or stroke (Adams and Young, 1970). Only the latter two tests are still done routinely today. Computed tomography (CT), positron emission tomography (PET), and magnetic resonance imaging (MRI) scans, which are the main scans used today, were not yet available.

Received Aug. 3, 2009; revised Aug. 11, 2009; accepted Aug. 14, 2009.

I acknowledge the National Institute on Aging and the National Institute of Neurological Disorders and Stroke for support. I thank Ellen B. Penney, Nancy S. Wexler, Brad Hyman, and Ippolita Cantuti-Castelvetri for helpful comments and suggestions.

Correspondence should be addressed to Anne B. Young, Neurology Service, ACC 720, Massachusetts General Hospital, Boston, MA 02114. E-mail: abyoung@partners.org.

DOI:10.1523/JNEUROSCI.3767-09.2009

Copyright $\odot 2009$ Society for Neuroscience $\quad$ 0270-6474/09/2912722-07\$15.00/0
Although examination of the living brain was difficult 40 years ago, pathological studies of postmortem human brains had been performed for decades. These pathological descriptions, however, depended mostly on the standard histological techniques of the day (hematoxylin and eosin, which stain proteins pink and nucleotides purple, respectively, as well as silver stains, which stain proteins and DNA black). Only a few neurochemical studies appeared in these years and there was no use of immunohistochemistry in that era of neuropathology. Even once immunohistochemistry of the CNS was introduced in the 1970s (Fuxe et al., 1970; LaVail and LaVail, 1974; McLaughlin et al., 1974; Saito et al., 1974), the human brain was for the most part ignored until the 1980s.

Work on neurodegenerative disease was not a major focus in neurology or neuroscience 40 years ago. When one searches PubMed for "Alzheimer" in 1969, only three articles are found. The most studied neurodegenerative disease was Parkinson's disease, followed by dementia, amyotrophic lateral sclerosis (ALS), and Huntington's disease. In the last 40 years, neurodegenerative disease research has blossomed, so that today there are journals entirely devoted to neurodegenerative diseases and articles on them are also prominent in all the major journals.

\section{General state of neuroscience}

Neuroanatomy was a prominent area of neuroscience in 1969, and neuroanatomists were doing beautiful work examining neurons, glia, myelin, and synapse structure at the light and electron microscopic levels. Neuroanatomists, however, were not yet mapping neuronal connections with tracers. Instead, the main way neural pathways were traced was by making lesions and then doing silver stains to identify degenerating fibers and terminals (Fink and Heimer, 1967). Then, in the 1970s and 1980s, methods to use horseradish peroxidase to trace pathways became popular (Ochs, 1972; Graybiel and Devor, 1974), and our understanding of neural circuitry advanced at a more rapid pace.

One discovery enabled an important advance in our ability to examine specific pathways. The natural neurotoxin kainic acid, or kainate, was found to kill neurons directly but not damage axons of passage when given systemically or microinjected stereotactically into animal brain nuclei (Cooper, 1956; Olney et al., 1974; Coyle and Schwarcz, 1976). Tiny lesions could be made and 
then degenerating terminals from those cells identified by the Fink-Heimer technique (Fink and Heimer, 1967). Biochemical assays could be done in the projection areas to define neurotransmitters associated with these pathways (Penney and Young, 1981; Bromberg et al., 1987).

Neurophysiology in 1969 was quite sophisticated and was a major focus of neuroscience at this time. Both intracellular and extracellular recordings of CNS neurons were being done routinely (Brock et al., 1952; Eccles, 1952). Neurotransmission at the neuromuscular junction and at the input from the 1a afferent to the motor neuron showed a synaptic delay of $\sim 0.5$ $\mathrm{ms}$ that could not be decreased experimentally. This observation was thought to be evidence of chemical transmission (Mountcastle and Baldessarini, 1968).

At the time, neurochemistry was defining the levels of amino acids, lipids, small peptides, and metabolic pathways in brain. Glutamate, glycine, and most peptides were found to have neuroactive properties, but they were not known to be neurotransmitters (Cooper et al., 1970). Various neurotransmitter receptors were largely unknown, except physiologically, including the catecholamines, serotonin, and acetylcholine receptors (Cooper et al., 1970).

\section{Neurotransmitters in neurodegenerative diseases}

Dopamine in Parkinson's disease

In 1969, the Society for Neuroscience was founded. The most impressive discovery made in the previous decade about neurodegenerative disease was that loss of dopaminergic cells in the substantia nigra causes Parkinson's disease and that the symptoms could be treated with levo-3,4-dihydroxyphenylalanine (L-DOPA), a dopamine precursor. As a beginning medical student in 1969, I'll never forget the class in which a person with Parkinson's disease came up on the stage of the lecture hall. $\mathrm{He}$ was stooped over and could barely walk. His hands were glued to his side and shook. His voice was nearly unintelligible. He was given a dose of L-DOPA and asked to sit down. The professor gave his talk and at the end called the patient to come up on stage again. It was like the Lazarus effect! He jumped up and came quickly swinging his arms and walking with agility. His voice had returned and he related what a miracle this drug was for him.

This incredible medical advance was made possible by the work of several researchers in the 1950s. Carlsson had discovered that reserpine depleted dopamine in the brains of animal models. These animals developed the reserpine syndrome: slowness and rigidity similar to that seen in Parkinson's disease, and importantly, L-DOPA reversed these symptoms (Carlsson et al., 1957; Carlsson, 1959). Shortly after, Ehringer and Hornykiewicz (1960) described a loss of dopamine in the brains of individuals who died with Parkinson's disease. Birkmayer and Hornykiewicz (1961) then described the beneficial effects of a single intravenous dose of L-DOPA administered to patients with Parkinson's disease. The next decade of research resulted in mapping the dopamine pathways (Dahlstroem et al., 1964) and assessing their effects on movement and behavior via administration of reserpine or the toxin 6-hydroxydopamine in animal models of Parkinson's disease (Ungerstedt, 1968). Investigators also measured dopamine content in the brains of people who died with Parkinson's disease, as well as other neurochemicals such as GABA, serotonin, norepinephrine, and epinephrine (Bernheimer et al., 1961; Bernheimer and Hornykiewicz, 1965; McGeer et al., 1973; McGeer and McGeer, 1976; Penney and Young, 1982; Young et al., 1983; Kish et al., 1986, 1987). At the same time, L-DOPA was developed as a therapy for patients suffering from Parkinson's disease (Cotzias et al., 1968; Yahr et al., 1968). This discovery has changed the lives of millions of patients with Parkinson's disease and remains one of the most important advances for treating neurodegenerative disorders.

In 1979, an experiment of nature took place that changed our thinking about Parkinson's disease. A drug addict attempted to make meperidine in his own home laboratory. After taking the preparation, the addict developed severe parkinsonism, and a postmortem examination showed a loss of dopaminergic neurons in the substantia nigra (Davis et al., 1979). It was discovered that the preparation-by mistake - contained 1-methyl-4phenyl-1,2,3,6-tetrahydropyridine (MPTP) (Langston et al., 1983). MPTP is a very potent dopamine neurotoxin. A metabolite, MPP +, is taken up selectively into dopamine cells (Javitch and Snyder, 1984; Langston et al., 1984), where it poisons complex I of the mitochondrial electron transport chain (Kindt et al., 1987; Mizuno et al., 1987). The use of MPTP- experimentally in mice, rats, and primates to create models of Parkinson's disease- has advanced our understanding of the mechanisms and consequences of dopamine cell death. Several people who had injected subclinically toxic doses of MPTP were subsequently found to have decreased dopamine terminals on PET scans (Calne et al., 1985). Some of these individuals have since developed Parkinson's disease and illustrate how environmental exposures can predispose people to dopaminergic cell death (Vingerhoets et al., 1994).

\section{GABA in Huntington's disease}

During the 1970s, detailed reports of the selective neuronal vulnerability in various neurodegenerative diseases were common. Parkinson's and Huntington's diseases were thought to be subcortical diseases and Alzheimer's disease (AD) a cortical and hippocampal disease. After the success of discovering dopamine to be a critical factor in Parkinson's disease, detailed studies of the distribution of various neurotransmitters, including neurotransmitter precursors and neurotransmitter metabolites, were made in postmortem human control and diseased brains. Many of these studies were dependent on freezing samples of postmortem brain so that biochemical studies could be done, and brain banking became critical for studying neurodegenerative disorders (Bird and Vonsattel, 1993).

In Huntington's disease, GABAergic markers were found to be selectively decreased in the striatum (Bird et al., 1973; McGeer et al., 1973; Perry et al., 1973). This observation was accompanied by the prediction that GABA agonists might help HD the way L-DOPA helped PD. Unfortunately, the GABA agonists in HD did not result in the same Lazarus effect that was seen with L-DOPA in PD. This is due, in part, to the fact that the GABAergic striatal efferents synapse with pallidal GABAergic neurons, resulting in disinhibition of the thalamus, a target of the pallidum (Roberts, 1974; Penney and Young, 1981). GABAergic agonists will act on the GABA receptors in pallidum and thalamus, thereby negating the double inhibition.

\section{Acetylcholine in Alzheimer's disease}

Similar to Huntington's disease, neurotransmitter studies were of limited use for unraveling Alzheimer's disease. Acetylcholine levels, however, were found to be markedly decreased, first in the cerebral cortex and subsequently in the basal forebrain of individuals with AD (Davies and Maloney, 1976; Whitehouse et al., 1981). Choline as a precursor and cholinesterase inhibitors were all predicted to be beneficial in patients with AD (Davies, 1979; Maire and Wurtman, 1984). Cholinesterase inhibitors 
are one class of drugs now used to treat $\mathrm{AD}$, but they produce very modest improvements, at best (Comfort, 1978; Rabins and Lyketsos, 2006).

\section{Protein aggregates in neurodegenerative diseases}

During the 1960s and 1970s, Glenner was attempting to purify and characterize various amyloid proteins, including those found in brains of people who died with Alzheimer's or Down's syndrome. After decades of perseverance, in 1984, he was finally successful. He described the first purification of the $\beta$-amyloid protein (Glenner and Wong, 1984). Around the same time, researchers were closing in on the other protein critical to unraveling Alzheimer's disease, tau, the phosphorylated form of which forms neurofibrillary tangles. Cleveland, Hwo, and Kirschner first purified tau in 1977 (Cleveland et al., 1977). These two proteins, $\beta$-amyloid (a major component of senile plaques) and tau (the protein making up neurofibrillary tangles) deservedly became the focus of attention in the Alzheimer research field. There were the "BAPtists" (BAP $=\beta$ amyloid protein) and the "tauists," who each claimed that their protein was most likely to cause AD (Trojanowski, 2002). The BAPtists dominated, but meetings were heated and sometimes rancorous between the two groups. This is still a hot topic, especially as there are other neurodegenerative disorders in which the primary pathology is exemplified by changes in tau (for example, frontotemporal dementias), leading to the idea that many diseases should be classified as tauopathies (Bird et al., 1997; Spillantini and Goedert, 1998).

The study of protein aggregates was advanced in the 1980s because immunohistochemistry of postmortem human brain was developing as an important tool in neuropathology. Before that, most brain was preserved in formalin or frozen. Once brain banks began preserving samples of key brain areas preserved in paraformaldehyde or other fixatives that allow the use of protein specific antibodies, our understanding of cellular changes in disease progressed rapidly.

One important discovery that immunohistochemistry enabled is that many neurodegenerative disorders are characterized by accumulations of misfolded and aggregated proteins. Sometimes these aggregates were not observed until the disease gene was identified and antibodies could be made against the diseaseassociated protein, but we now know them to be a universal feature of neurodegeneration (Trojanowski and Lee, 2001). In Alzheimer's disease, there are intraneuronal and extraneuronal aggregates. HD, PD, and ALS are characterized by intraneuronal aggregates. For many diseases, the native protein is unfolded$\beta$-amyloid, synuclein, tau, and the androgen receptor-and when these proteins aggregate, they can wreak havoc (Klucken et al., 2004; Selkoe, 2008; Williams and Paulson, 2008; Spires-Jones et al., 2009a).

In recent years, much research has focused on how and why aggregation occurs and what could be done to prevent it. Chaperones play a critically important role in degrading misfolded proteins by refolding them or leading them to be cleared from the cell (Klucken et al., 2004). The proteasome and autophagy are other vital cellular processes in clearing misfolded proteins (Goldberg, 2003, 2007; Levine and Kroemer, 2008). Mitochondrial dysfunction also plays a crucial role in clearance (since free radicals react with proteins and disrupt their tertiary structure) (Medicherla and Goldberg, 2008; Karch et al., 2009). Interestingly, the initial view that aggregates are detrimental has been challenged more recently. Now the current view is that misfolded protein monomers or oligomers might be the toxic species and that the larger aggregates might be neutral or protective (Selkoe, 2008; Williams and Paulson, 2008; Spires-Jones et al., 2009a). Numerous researchers are exploring how aggregation might be altered to prevent toxicity.

\section{The imaging revelation}

When I was a neurology resident at University of California, San Francisco, we did not have a CT scanner until 1976. Then the hospital scanner was reserved for only the most serious cases. Soon after, the MRI scanner came along. The resolution of the MRI was astounding, even in the early years of its development. It was like taking a picture from an atlas. Positron emission tomography scanning to examine brain function came in at multiple institutions in the 1980s. Together with CTs and MRIs, brain imaging became very sophisticated.

Imaging was immediately applied to the study of living patients with neurodegenerative diseases (de Leon et al., 1983; van Oostrom et al., 2005; Foster et al., 2007; Brooks, 2008). We can now look at the earliest stages of disease, not wait until the end stages, witnessed at postmortem. The most frequently used ligand for PET imaging is $\left[{ }^{18} \mathrm{~F}\right]$-2-deoxy-glucose (FDG), which is used for imaging patients with epilepsy or dementia. FDG uptake is characteristically altered in all the neurodegenerative diseases. Abnormalities of FDG uptake in $\mathrm{HD}, \mathrm{PD}$, and $\mathrm{AD}$ have been seen presymptomatically and are now being followed longitudinally to see how the changes relate to disease onset (van Oostrom et al., 2005; Eckert et al., 2007; Feigin et al., 2007). Sophisticated imaging with dopamine ligands is revealing presymptomatic alterations in $\mathrm{PD}$ as well as early changes in $\mathrm{D}_{2}$ dopamine receptors in HD (Bohnen et al., 2006; Bohnen and Frey, 2007; Stoessl, 2007). Although PET scanning can demonstrate even subtle changes, currently, it is prohibitively expensive to serve as a widely used biomarker.

\section{The genetic revolution}

In April, 1953, James Watson and Francis Crick reported the discovery of the structure of DNA (Watson and Crick, 1953). Their letter to Nature sent shock waves around the world. Not only was the structure of DNA solved, but the way in which genetic information informs the future was evident just by the way DNA replicates. This incredible discovery set the stage for the genetic revolution that included the discovery of many disease genes and culminated in the sequencing of the human genome.

Surprisingly, Huntington's disease, a relatively rare disorder, played a crucial role in this revolution. In October, 1979, the Hereditary Disease Foundation held a workshop, organized by David Housman, a molecular biologist at Massachusetts Institute of Technology, which focused on how to use DNA markers to find the HD gene. Workshop participants proposed to map the entire human genome and then look for a marker that segregated with the HD gene- a process that could take over 100 years to accomplish, given then current technology.

The Hereditary Disease Foundation, Milton and Nancy Wexler, together with the National Institute of Neurological Disorders and Stroke, decided to pursue this strategy to find the HD gene. In 1981, they organized the Venezuela Project-a group of interdisciplinary investigators who went to Venezuela to search for the HD gene. Venezuela was home to the largest known HD kindreds. The team conducted clinical examinations and collected blood for DNA extraction.

In 1983, much to everyone's shock and amazement, a DNA marker was discovered on the top of chromosome 4, tightly linked to the HD gene (Gusella et al., 1983)! The speed of this 
discovery astonished everyone! With the DNA marker in hand, the Hereditary Disease Foundation organized the "Gene Hunters," also an international, collaborative group to identify the HD gene itself. It took fully a decade to isolate the HD gene (The Huntington's Disease Collaborative Research Group, 1993). Many of the technological innovations created by the group were used to advance the Human Genome Project and proved that the Human Genome Project could work.

The HD gene creates a protein called huntingtin, and the disease mutation causes an expansion of CAG repeats in the gene, which is translated into an abnormal stretch of polyglutamines in the protein. Unraveling the cause of HD helped the discovery of other expanded repeat diseases - many of which also cause neurodegeneration-such as the spinocerebellar ataxias (Orr et al., 1993), Kennedy's disease, or spinal bulbar muscular atrophy (La Spada et al., 1991), among others. The techniques developed, the DNA from an enormous multigenerational family, and the genome maps used to isolate the HD gene led directly to the discovery of a gene for the amyloid precursor protein (Tanzi et al., 1987; Tanzi, 1989), which causes Alzheimer's disease, and to finding the superoxide dismutase gene (SOD1), which causes an inherited form of ALS (Rosen, 1993).

Study of additional families yielded more disease-causing genes, such as presenilin for AD (Sherrington et al., 1995), and in the late 1990s, the $\alpha$-synuclein protein, for Parkinson's disease, was discovered (Polymeropoulos et al., 1997). Now we know that multiple genes are associated with AD, PD, and ALS (Gasser, 2007; Bertram and Tanzi, 2008; Valdmanis and Rouleau, 2008). What were thought to be specific "diseases" are actually multiple disorders caused by multiple genes that produce similar phenotypes and pathologies. The discovery of genes causing these neurodegenerative disorders has sparked a huge effort to identify the function of the native and mutant proteins. As soon as gene mutations are isolated, the proteins encoded by these genes are identified and antibodies made against them. In situ hybridizations for mRNA and immunohistochemistry for the proteins are performed. Attention is riveted on elucidating these disease proteins themselves, their distribution and function in animal and human brain.

\section{Animal models}

Animal models of neurodegenerative disease have existed since the late 1950s, when reserpine was used to deplete dopamine and cause a Parkinson's-like phenotype in animals (Carlsson et al., 1957). For the next three decades, animal models consisted primarily of using toxins such as 6-hydroxydopamine, kainate, and quinolinate, to create lesions in specific brain regions to mimic various diseases (Ungerstedt, 1968; Schwarcz and Coyle, 1977; Schwarcz and Köhler, 1983). Strains of mice with spontaneous mutations were also studied. These animal models, despite their problems, played an important role in the elucidation of basic functional neuroanatomy and circuitry but could not help us address the underlying disease mechanisms.

The importance of animal disease models has changed drastically in the last decade and a half because the identification of disease genes has allowed the creation of new models. Transgenic animals expressing the human mutant genes have been created, as have models in which the animals' endogenous diseaseassociated gene has been mutated. The insights generated by studying these animals have revolutionized our understanding of these complex human diseases. In the past decade, molecular twists have been used to create transgenic models in which the transgene can be turned on and off and even selectively expressed in only certain neurons. Knock-in and knock-out models of genetic defects have also been made. In this genetic era, there are cell, yeast, fly (Drosophila), and worm (Caenorhabditis elegans) models of neurodegenerative diseases. Most recently, to study more sophisticated transgenic models of HD, sheep, pig, and primate models have been made.

These animal models have proved to be powerful tools for studying the biology underlying the disease process. Normal and abnormal protein function can be studied in vivo to identify protein interactors and elucidate the involved molecular pathways. Genetic screens in invertebrate models of neurodegenerative disease (including yeast) enable the identification of suppressors or enhancers that can modify the disease phenotype. Environmental conditions can be altered to study the intersection of genetics and the environment. For instance, HD is an autosomal dominant disease characterized by almost complete penetrance. The age of onset is inversely correlated with the CAG repeat size in $\mathrm{HD}$, and yet $44 \%$ of the remaining variability is accounted for by other modifying genes and environmental effects (Wexler et al., 2004). Animal models will allow the interaction of each predisposing factor to be studied. Finally, and perhaps most importantly, all of these processes can be studied throughout disease development-from the preclinical stage to advanced disease.

As new technologies have been developed over the decades, their application to animal models has led to important discoveries. For example, laser capture microdissection of transgenic animal models and even postmortem human brain gives us the capacity to analyze individual neurons quickly and efficiently (Bernard et al., 2009). We can capture levels of mRNA and protein in each neuron plucked from the neuropil. For the first time, this has enabled us to determine directly how different disease proteins act in specific cell types and may help us finally understand selective neuronal vulnerability.

Imaging advances have been particularly important for the study of disease models. The use of lasers in microscopes has changed the resolution of immunohistochemistry, and the development of fluorescent tags (Tsien, 2009) allows proteins to be tracked in living animals. Recently, multiphoton imaging has revealed senile plaques caught at the moment of creation. The skull of a transgenic Alzheimer's mouse is burred to a thin translucent covering so the brain underneath can be imaged, and intravenous thioflavin is used to label the plaques. One can image the same plaque every day-for weeks! One can also see the appearance of each new plaque. Brad Hyman used this approach to show that plaques can form in a day and then remain stable over many weeks (Meyer-Luehmann et al., 2008). Amazingly, antibodies to $\beta$-amyloid reduced both plaque size and number (Spires-Jones et al., 2009b). This latter finding supports the use of vaccines or passive immunotherapy for $\mathrm{AD}$ and illustrates how these new techniques in animal models can fundamentally change our understanding of the disease process and its permanence.

\section{Preclinical testing}

Transgenic models of neurodegenerative diseases have played critical roles in testing the clinical benefits of experimental therapies, purported to be effective for these diseases. Preclinical trials in animal models can be done in weeks or months rather than the years or decades required for human studies. "Protective" or "preventative" therapies can be directed at the primary protein defect, the proteins encoded by modifying genes, and the secondary effects on cellular health and energy production. The goals of these "protective" trials are to delay onset and slow progression of 
the disease. Demonstration of preclinical efficacy can lead to new clinical trials in humans.

\section{Therapeutics \\ Functional neurosurgery approaches—lesions, stimulation, and transplants}

In the 1990s, treatment of Parkinson's disease went full circle. In the 1950s, before L-DOPA, stereotaxic surgery was used to put lesions in the pallidum and the thalamus to treat Parkinson's disease (Cooper, 1956; Hullay, 1971). Destructive lesions were made with alcohol, freezing, or radio frequency pulses. Surgery was reintroduced two decades later because the advances in imaging and electrophysiology allowed for more accurate localization of the lesion (Bakay et al., 1992; Laitinen et al., 1992). Curiously, these lesions ameliorate both symptoms of Parkinson's disease and L-DOPA-induced dyskinesias. This latter observation flies in the face of a popular theory of basal ganglia structure and function (Penney and Young, 1986; Albin et al., 1989; Alexander et al., 1990; DeLong, 1990). Why these lesions are effective in attenuating dyskinesias is still a mystery (Albin et al., 1995). More recently, the use of battery-implanted deep brain stimulation of the subthalamic nucleus is a popular therapy for patients with Parkinson's disease. It is especially effective for treating those with "on/off" symptoms and dyskinesia (Limousin et al., 1995a,b).

These lesion/stimulation treatments, however, will never offer more than symptomatic alleviation. This has led to recent attempts at transplant therapeutics that have potential to replace the lost neurons. Currently, the transplants being tried include fetal transplants and cellular transplants expressing growth factors and enzymes. Embryonic stem cells as well as induced pluripotent stem cells are also being developed with enthusiasm to create therapies for neurodegenerative diseases (Abeliovich and Doege, 2009). Early studies show promise for transplants, although in a recent study in Parkinson's disease, transplants survived but the transplants also developed PD pathology (Kordower et al., 2008), demonstrating that more research into these techniques needs to be done.

\section{Drug design}

Target-based drug design has been possible over the last four decades. Each era has had its own frontiers, targets, and successes. In the 1970s, the latest hypotheses in targeted therapy rested on the notion that effective therapy would consist of neurotransmitter replacement by giving precursors, releasing agents, uptake inhibitors, enzyme inhibitors, direct receptor agonists, and second messenger modulators.

In the last two decades, focus has shifted to the problem of protein aggregation. The synthesis, processing, and metabolism of the various proteins found to accumulate in the neurodegenerative disorders have been addressed. More recently, regulation of transcription and mRNA for particular proteins is also being targeted to control levels of abnormal proteins. RNA interference is an extremely promising avenue for therapeutics. Recently, antisense strategies-introduced by virus or by cells-are being vigorously pursued.

Excitingly, we now believe that these therapies might be able to do more than simply prevent disease progression and delay onset, because an important piece of research has changed our way of thinking about neurodegenerative disorders. The neurodegenerative process can be turned off and, more impressively, reversed if caught in the early stages (Yamamoto et al., 2000). Furthermore, new data, obtained by multiphoton microscopy and other techniques, have shown that turnover of many culprit proteins is rapid-rather than slow (Meyer-Luehmann et al., 2008; Spires-Jones et al., 2009b). Aggregates can form quickly and dissolve. Conditional models of Huntington's disease revealed striking reversibility in caudate size, GFAP staining, aggregates, $\mathrm{D}_{1}$ dopamine receptor levels, and, most importantly, behavior (Yamamoto et al., 2000). Once not under attack by the mutant protein, cells are able to discard the detritus of aging and rejuvenate themselves!

\section{The next 40 years}

In the next 40 years, our goal is to have therapies that delay the onset and even reverse the symptoms of neurodegenerative diseases. Therapies will be personalized on the basis of genetic and biochemical studies. Biomarkers such as imaging and blood proteomics and/or metabolomics will be used as screening tools and predictors of subsequent disease. Effective cures will normalize the biomarkers. In 40 years, I predict that we will have silver bullets for neurodegenerative diseases.

In experimental models, clever genetic techniques and drugs have been used to correct the effects of mutations. For instance, in spinal muscular atrophy, oligonucleotides or drugs are being successfully used to jump a splicing defect in the SMA2 gene (Mattis et al., 2009; Williams et al., 2009). This gene could be used to make a normal protein that would take the place of mutations in the SMA1 gene. The challenge with all such therapies is the delivery of antisense oligonucleotides or other genetic tools to the whole brain.

Neurodegenerative diseases, collectively, are the leading cause of disability in the elderly. And science moves in baby steps-with an occasional leap to accommodate a paradigm shift. But I predict that research in these neurodegenerative disorders will accelerate over the coming years as tools and insights gain momentum. We are poised now to look deeper into cellular and genetic processes to understand fundamental insights and bring them creatively to the fore for novel therapeutics.

\section{References}

Abeliovich A, Doege CA (2009) Reprogramming therapeutics: iPS cell prospects for neurodegenerative disease. Neuron 61:337-339.

Adams RD, Young RR (1970) Harrison's principles of internal medicine, Ed 6. New York: McGraw-Hill.

Albin RL, Young AB, Penney JB (1989) The functional anatomy of basal ganglia disorders. Trends Neurosci 12:366-375.

Albin RL, Young AB, Penney JB (1995) The functional anatomy of disorders of the basal ganglia. Trends Neurosci 18:63-64.

Alexander GE, Crutcher MD, DeLong MR (1990) Basal ganglia-thalamocortical circuits: parallel substrates for motor, oculomotor, "prefrontal" and "limbic" functions. Prog Brain Res 85:119-146.

Bakay RA, DeLong MR, Vitek JL (1992) Posteroventral pallidotomy for Parkinson's disease. J Neurosurg 77:487-488.

Bernard R, Kerman IA, Meng F, Evans SJ, Amrein I, Jones EG, Bunney WE, Akil H, Watson SJ, Thompson RC (2009) Gene expression profiling of neurochemically defined regions of the human brain by in situ hybridization-guided laser capture microdissection. J Neurosci Methods 178:46-54.

Bernheimer H, Hornykiewicz O (1965) [Decreased homovanillic acid concentration in the brain in parkinsonian subjects as an expression of a disorder of central dopamine metabolism]. Klin Wochenschr 43: 711-715.

Bernheimer H, Birkmayer W, Hornykiewicz O (1961) [Distribution of 5-hydroxytryptamine (serotonin) in the human brain and its behavior in patients with Parkinson's syndrome.]. Klin Wochenschr 39:1056-1059.

Bertram L, Tanzi RE (2008) Thirty years of Alzheimer's disease genetics: the implications of systematic meta-analyses. Nat Rev Neurosci 9:768-778.

Bird ED, Vonsattel JP (1993) The development of a brain bank. J Neural Transm Suppl 39:17-23. 
Bird ED, Mackay AV, Rayner CN, Iversen LL (1973) Reduced glutamicacid-decarboxylase activity of post-mortem brain in Huntington's chorea. Lancet 1:1090-1092.

Bird TD, Wijsman EM, Nochlin D, Leehey M, Sumi SM, Payami H, Poorkaj P, Nemens E, Rafkind M, Schellenberg GD (1997) Chromosome 17 and hereditary dementia: linkage studies in three non-Alzheimer families and kindreds with late-onset FAD. Neurology 48:949-954.

Birkmayer W, Hornykiewicz O (1961) [The L-3,4-dioxyphenylalanine (DOPA)-effect in Parkinson-akinesia.]. Wien Klin Wochenschr 73:787-788

Bohnen NI, Frey KA (2007) Imaging of cholinergic and monoaminergic neurochemical changes in neurodegenerative disorders. Mol Imaging Biol 9:243-257.

Bohnen NI, Albin RL, Koeppe RA, Wernette KA, Kilbourn MR, Minoshima S, Frey KA (2006) Positron emission tomography of monoaminergic vesicular binding in aging and Parkinson disease. J Cereb Blood Flow Metab 26:1198-1212.

Brock LG, Coombs JS, Eccles JC (1952) The recording of potentials from motoneurones with an intracellular electrode. J Physiol 117:431-460.

Bromberg MB, Pamel G, Stephenson BS, Young AB, Penney JB (1987) Evidence for reactive synaptogenesis in the ventrolateral thalamus and red nucleus of the rat: changes in high affinity glutamate uptake and numbers of corticofugal fiber terminals. Exp Brain Res 69:53-59.

Brooks DJ (2008) The role of structural and functional imaging in parkinsonian states with a description of PET technology. Semin Neurol 28:435-445.

Calne DB, Langston JW, Martin WR, Stoessl AJ, Ruth TJ, Adam MJ, Pate BD, Schulzer M (1985) Positron emission tomography after MPTP: observations relating to the cause of Parkinson's disease. Nature 317:246-248.

Carlsson A (1959) The occurrence, distribution and physiological role of catecholamines in the nervous system. Pharmacol Rev 11:490-493.

Carlsson A, Lindqvist M, Magnusson T (1957) 3,4-Dihydroxyphenylalanine and 5-hydroxytryptophan as reserpine antagonists. Nature 180:1200.

Cleveland DW, Hwo SY, Kirschner MW (1977) Purification of tau, a microtubule-associated protein that induces assembly of microtubules from purified tubulin. J Mol Biol 116:207-225.

Comfort A (1978) Cholinesterase inhibition in treatment of Alzheimer's dementia. Lancet 1:659-660.

Cooper IS (1956) Neurosurgical alleviation of parkinsonism. Bull N Y Acad Med 32:713-724.

Cooper JR, Bloom FE, Roth RH (1970) The biochemical basis of neuropharmacology, Ed 1. New York: Oxford UP.

Cotzias GC, Papavasiliou PS, Gellene R (1968) Experimental treatment of parkinsonism with L-Dopa. Neurology 18:276-277.

Coyle JT, Schwarcz R (1976) Lesion of striatal neurones with kainic acid provides a model for Huntington's chorea. Nature 263:244-246.

Dahlstroem A, Fuxe K, Olson L, Ungerstedt U (1964) Ascending systems of catecholamine neurons from the lower brain stem. Acta Physiol Scand 62:485-486.

Davies P (1979) Biochemical changes in Alzheimer's disease-senile dementia: neurotransmitters in senile dementia of the Alzheimer's type. Res Publ Assoc Res Nerv Ment Dis 57:153-166.

Davies P, Maloney AJ (1976) Selective loss of central cholinergic neurons in Alzheimer's disease. Lancet 2:1403.

Davis GC, Williams AC, Markey SP, Ebert MH, Caine ED, Reichert CM, Kopin IJ (1979) Chronic Parkinsonism secondary to intravenous injection of meperidine analogues. Psychiatry Res 1:249-254.

de Leon MJ, Ferris SH, George AE, Christman DR, Fowler JS, Gentes C, Reisberg B, Gee B, Emmerich M, Yonekura Y, Brodie J, Kricheff II, Wolf AP (1983) Positron emission tomographic studies of aging and Alzheimer disease. AJNR Am J Neuroradiol 4:568-571.

DeLong MR (1990) Primate models of movement disorders of basal ganglia origin. Trends Neurosci 13:281-285.

Eccles JC (1952) The electrophysiological properties of the motoneurone. Cold Spring Harb Symp Quant Biol 17:175-183.

Eckert T, Tang C, Eidelberg D (2007) Assessment of the progression of Parkinson's disease: a metabolic network approach. Lancet Neurol 6:926-932.

Ehringer H, Hornykiewicz O (1960) [Distribution of noradrenaline and dopamine (3-hydroxytyramine) in the human brain and their behavior in diseases of the extrapyramidal system.]. Klin Wochenschr 38:1236-1239.

Feigin A, Tang C, Ma Y, Mattis P, Zgaljardic D, Guttman M, Paulsen JS,
Dhawan V, Eidelberg D (2007) Thalamic metabolism and symptom onset in preclinical Huntington's disease. Brain 130:2858-2867.

Fink RP, Heimer L (1967) Two methods for selective silver impregnation of degenerating axons and their synaptic endings in the central nervous system. Brain Res 4:369-374.

Foster NL, Heidebrink JL, Clark CM, Jagust WJ, Arnold SE, Barbas NR, DeCarli CS, Turner RS, Koeppe RA, Higdon R, Minoshima S (2007) FDG-PET improves accuracy in distinguishing frontotemporal dementia and Alzheimer's disease. Brain 130:2616-2635.

Fuxe K, Goldstein M, Hökfelt T, Joh TH (1970) Immunohistochemical localization of dopamine-hydroxylase in the peripheral and central nervous system. Res Commun Chem Pathol Pharmacol 1:627-636.

Gasser T (2007) Update on the genetics of Parkinson's disease. Mov Disord 22:S343-S350.

Glenner GG, Wong CW (1984) Alzheimer's disease: initial report of the purification and characterization of a novel cerebrovascular amyloid protein. Biochem Biophys Res Commun 120:885-890.

Goldberg AL (2003) Protein degradation and protection against misfolded or damaged proteins. Nature 426:895-899.

Goldberg AL (2007) Functions of the proteasome: from protein degradation and immune surveillance to cancer therapy. Biochem Soc Trans 35:12-17.

Graybiel AM, Devor M (1974) A microelectrophoretic delivery technique for use with horseradish peroxidase. Brain Res 68:167-173.

Gusella JF, Wexler NS, Conneally PM, Naylor SL, Anderson MA, Tanzi RE, Watkins PC, Ottina K, Wallace MR, Sakaguchi AY, Young AB, Shoulson I, Bonilla E, Martin JB (1983) A polymorphic DNA marker genetically linked to Huntington's disease. Nature 306:234-238.

Hullay J (1971) Subthalamotomy in Parkinson's disease. Analysis of responses to electrostimulation. Acta Med Acad Sci Hung 28:57-68.

Javitch JA, Snyder SH (1984) Uptake of MPP(+) by dopamine neurons explains selectivity of parkinsonism-inducing neurotoxin, MPTP. Eur J Pharmacol 106:455-456.

Karch CM, Prudencio M, Winkler DD, Hart PJ, Borchelt DR (2009) Role of mutant SOD1 disulfide oxidation and aggregation in the pathogenesis of familial ALS. Proc Natl Acad Sci U S A 106:7774-7779.

Kindt MV, Heikkila RE, Nicklas WJ (1987) Mitochondrial and metabolic toxicity of 1-methyl-4-(2'-methylphenyl)-1,2,3,6-tetrahydropyridine. J Pharmacol Exp Ther 242:858-863.

Kish SJ, Rajput A, Gilbert J, Rozdilsky B, Chang LJ, Shannak K, Hornykiewicz O (1986) Elevated gamma-aminobutyric acid level in striatal but not extrastriatal brain regions in Parkinson's disease: correlation with striatal dopamine loss. Ann Neurol 20:26-31.

Kish SJ, Shannak K, Hornykiewicz O (1987) Elevated serotonin and reduced dopamine in subregionally divided Huntington's disease striatum. Ann Neurol 22:386-389.

Klucken J, Shin Y, Masliah E, Hyman BT, McLean PJ (2004) Hsp70 reduces alpha-synuclein aggregation and toxicity. J Biol Chem 279:25497-25502.

Kordower JH, Chu Y, Hauser RA, Freeman TB, Olanow CW (2008) Lewy body-like pathology in long-term embryonic nigral transplants in Parkinson's disease. Nat Med 14:504-506.

Laitinen LV, Bergenheim AT, Hariz MI (1992) Leksell's posteroventral pallidotomy in the treatment of Parkinson's disease. J Neurosurg 76:53-61.

Langston JW, Ballard P, Tetrud JW, Irwin I (1983) Chronic Parkinsonism in humans due to a product of meperidine-analog synthesis. Science 219:979-980.

Langston JW, Irwin I, Langston EB, Forno LS (1984) 1-Methyl-4phenylpyridinium ion (MPP+): identification of a metabolite of MPTP, a toxin selective to the substantia nigra. Neurosci Lett 48:87-92.

La Spada AR, Wilson EM, Lubahn DB, Harding AE, Fischbeck KH (1991) Androgen receptor gene mutations in X-linked spinal and bulbar muscular atrophy. Nature 352:77-79.

LaVail JH, LaVail MM (1974) The retrograde intraaxonal transport of horseradish peroxidase in the chick visual system: a light and electron microscopic study. J Comp Neurol 157:303-357.

Levine B, Kroemer G (2008) Autophagy in the pathogenesis of disease. Cell 132:27-42.

Limousin P, Pollak P, Benazzouz A, Hoffmann D, Broussolle E, Perret JE, Benabid AL (1995a) Bilateral subthalamic nucleus stimulation for severe Parkinson's disease. Mov Disord 10:672-674.

Limousin P, Pollak P, Benazzouz A, Hoffmann D, Le Bas JF, Broussolle E, 
Perret JE, Benabid AL (1995b) Effect of parkinsonian signs and symptoms of bilateral subthalamic nucleus stimulation. Lancet 345:91-95.

Maire JC, Wurtman RJ (1984) Choline production from choline-containing phospholipids: a hypothetical role in Alzheimer's disease and aging. Prog Neuropsychopharmacol Biol Psychiatry 8:637-642.

Mattis VB, Ebert AD, Fosso MY, Chang CW, Lorson CL (2009) Delivery of a read-through inducing compound, TC007, lessens the severity of a SMA animal model. Hum Mol Genet. Advance online publication. Retrieved August 31, 2009. doi:10.1093/hmg/ddp333.

McGeer PL, McGeer EG (1976) Enzymes associated with the metabolism of catecholamines, acetylcholine and GABA in human controls and patients with Parkinson's disease and Huntington's chorea. J Neurochem 26:65-76.

McGeer PL, McGeer EG, Fibiger HC (1973) Glutamic-acid decarboxylase and choline acetylase in Huntington's chorea and Parkinson's disease. Lancet 2:622-623.

McLaughlin BJ, Wood JG, Saito K, Barber R, Vaughn JE, Roberts E, Wu JY (1974) The fine structural localization of glutamate decarboxylase in synaptic terminals of rodent cerebellum. Brain Res 76:377-391.

Medicherla B, Goldberg AL (2008) Heat shock and oxygen radicals stimulate ubiquitin-dependent degradation mainly of newly synthesized proteins. J Cell Biol 182:663-673.

Meyer-Luehmann M, Spires-Jones TL, Prada C, Garcia-Alloza M, de Calignon A, Rozkalne A, Koenigsknecht-Talboo J, Holtzman DM, Bacskai BJ, Hyman BT (2008) Rapid appearance and local toxicity of amyloidbeta plaques in a mouse model of Alzheimer's disease. Nature 451: $720-724$.

Mizuno Y, Sone N, Saitoh T (1987) Effects of 1-methyl-4-phenyl-1,2,3,6tetrahydropyridine and 1-methyl-4-phenylpyridinium ion on activities of the enzymes in the electron transport system in mouse brain. J Neurochem 48:1787-1793.

Mountcastle VB, Baldessarini RJ (1968) Medical physiology, Ed 12. St. Louis: Mosby.

Ochs S (1972) Fast transport of materials in mammalian nerve fibers. Science 176:252-260.

Olney JW, Rhee V, Ho OL (1974) Kainic acid: a powerful neurotoxic analogue of glutamate. Brain Res 77:507-512.

Orr HT, Chung MY, Banfi S, Kwiatkowski TJ Jr, Servadio A, Beaudet AL, McCall AE, Duvick LA, Ranum LP, Zoghbi HY (1993) Expansion of an unstable trinucleotide CAG repeat in spinocerebellar ataxia type 1. Nat Genet 4:221-226.

Penney JB Jr, Young AB (1981) GABA as the pallidothalamic neurotransmitter: implications for basal ganglia function. Brain Res 207:195-199.

Penney JB Jr, Young AB (1982) Quantitative autoradiography of neurotransmitter receptors in Huntington disease. Neurology 32:1391-1395.

Penney JB Jr, Young AB (1986) Striatal inhomogeneities and basal ganglia function. Mov Disord 1:3-15.

Perry TL, Hansen S, Kloster M (1973) Huntington's chorea. Deficiency of gamma-aminobutyric acid in brain. N Engl J Med 288:337-342.

Polymeropoulos MH, Lavedan C, Leroy E, Ide SE, Dehejia A, Dutra A, Pike B, Root H, Rubenstein J, Boyer R, Stenroos ES, Chandrasekharappa S, Athanassiadou A, Papapetropoulos T, Johnson WG, Lazzarini AM, Duvoisin RC, Di Iorio G, Golbe LI, Nussbaum RL (1997) Mutation in the alpha-synuclein gene identified in families with Parkinson's disease. Science 276:2045-2047.

Rabins PV, Lyketsos CG (2006) Cholinesterase inhibitors and memantine have a role in the treatment of Alzheimer's disease. Nat Clin Pract Neurol 2:578-579.

Roberts E (1974) Disinhibition as an organizing principle in the nervous system. The role of gamma-aminobutyric acid. Adv Neurol 5:127-143.

Rosen DR (1993) Mutations in Cu/Zn superoxide dismutase gene are associated with familial amyotrophic lateral sclerosis. Nature 364:362.

Saito K, Barber R, Wu J, Matsuda T, Roberts E, Vaughn JE (1974) Immunohistochemical localization of glutamate decarboxylase in rat cerebellum. Proc Natl Acad Sci U S A 71:269-273.

Schwarcz R, Coyle JT (1977) Striatal lesions with kainic acid: neurochemical characteristics. Brain Res 127:235-249.

Schwarcz R, Köhler C (1983) Differential vulnerability of central neurons of the rat to quinolinic acid. Neurosci Lett 38:85-90.

Selkoe DJ (2008) Soluble oligomers of the amyloid beta-protein impair synaptic plasticity and behavior. Behav Brain Res 192:106-113.
Sherrington R, Rogaev EI, Liang Y, Rogaeva EA, Levesque G, Ikeda M, Chi H, Lin C, Li G, Holman K, Tsuda T, Mar L, Foncin J-F, Bruni AC, Montesi MP, Sorbi S, Rainero I, Pinessi L, Nee L, Chumakov I, et al.(1995) Cloning of a gene bearing missense mutations in early-onset familial Alzheimer's disease. Nature 375:754-760.

Spillantini MG, Goedert M (1998) Tau protein pathology in neurodegenerative diseases. Trends Neurosci 21:428-433.

Spires-Jones TL, Stoothoff WH, de Calignon A, Jones PB, Hyman BT (2009a) Tau pathophysiology in neurodegeneration: a tangled issue. Trends Neurosci 32:150-159.

Spires-Jones TL, Mielke ML, Rozkalne A, Meyer-Luehmann M, de Calignon A, Bacskai BJ, Schenk D, Hyman BT (2009b) Passive immunotherapy rapidly increases structural plasticity in a mouse model of Alzheimer disease. Neurobiol Dis 33:213-220.

Stoessl AJ (2007) Positron emission tomography in premotor Parkinson's disease. Parkinsonism Relat Disord 13 [Suppl 3]:S421-S424.

Tanzi RE (1989) Molecular genetics of Alzheimer's disease and the amyloid beta peptide precursor gene. Ann Med 21:91-94.

Tanzi RE, Gusella JF, Watkins PC, Bruns GA, St George-Hyslop P, Van Keuren ML, Patterson D, Pagan S, Kurnit DM, Neve RL (1987) Amyloid beta protein gene: cDNA, mRNA distribution, and genetic linkage near the Alzheimer locus. Science 235:880-884.

The Huntington's Disease Collaborative Research Group (1993) A novel gene containing a trinucleotide repeat that is expanded and unstable on Huntington's disease chromosomes. Cell 72:971-983.

Trojanowski JQ (2002) Tauists, Baptists, Syners, Apostates, and new data. Ann Neurol 52:263-265.

Trojanowski JQ, Lee VM (2001) Brain degeneration linked to "fatal attractions" of proteins in Alzheimer's disease and related disorders. J Alzheimers Dis 3:117-119.

Tsien RY (2009) Constructing and exploiting the fluorescent protein paintbox (Nobel Lecture). Angew Chem Int Ed Engl 48:5612-5626.

Ungerstedt U (1968) 6-Hydroxy-dopamine induced degeneration of central monoamine neurons. Eur J Pharmacol 5:107-110.

Valdmanis PN, Rouleau GA (2008) Genetics of familial amyotrophic lateral sclerosis. Neurology 70:144-152.

van Oostrom JC, Maguire RP, Verschuuren-Bemelmans CC, Veenma-van der Duin L, Pruim J, Roos RA, Leenders KL (2005) Striatal dopamine D2 receptors, metabolism, and volume in preclinical Huntington disease. Neurology 65:941-943.

Vingerhoets FJ, Snow BJ, Tetrud JW, Langston JW, Schulzer M, Calne DB (1994) Positron emission tomographic evidence for progression of human MPTP-induced dopaminergic lesions. Ann Neurol 36:765-770.

Watson JD, Crick FH (1953) Genetical implications of the structure of deoxyribonucleic acid. Nature 171:964-967.

Wexler NS, Lorimer J, Porter J, Gomez F, Moskowitz C, Shackell E, Marder K, Penchaszadeh G, Roberts SA, Gayán J, Brocklebank D, Cherny SS, Cardon LR, Gray J, Dlouhy SR, Wiktorski S, Hodes ME, Conneally PM, Penney JB, Gusella J, et al. (2004) Venezuelan kindreds reveal that genetic and environmental factors modulate Huntington's disease age of onset. Proc Natl Acad Sci U S A 101:3498-3503.

Whitehouse PJ, Price DL, Clark AW, Coyle JT, DeLong MR (1981) Alzheimer disease: evidence for selective loss of cholinergic neurons in the nucleus basalis. Ann Neurol 10:122-126.

Williams AJ, Paulson HL (2008) Polyglutamine neurodegeneration: protein misfolding revisited. Trends Neurosci 31:521-528.

Williams JH, Schray RC, Patterson CA, Ayitey SO, Tallent MK, Lutz GJ (2009) Oligonucleotide-mediated survival of motor neuron protein expression in CNS improves phenotype in a mouse model of spinal muscular atrophy. J Neurosci 29:7633-7638.

Yahr MD, Duvoisin RC, Hoehn MM, Schear MJ, Barrett RE (1968) L-Dopa (L-3,4-dihydroxyphenylanine)-its clinical effects in parkinsonism. Trans Am Neurol Assoc 93:56-63.

Yamamoto A, Lucas JJ, Hen R (2000) Reversal of neuropathology and motor dysfunction in a conditional model of Huntington's disease. Cell 101:57-66.

Young AB, Penney JB, Dauth GW, Bromberg MB, Gilman S (1983) Glutamate or aspartate as a possible neurotransmitter of cerebral corticofugal fibers in the monkey. Neurology 33:1513-1516. 